\title{
Survival and Molting Incidence after Heat and Cold Shocks in Panstrongylus megistus Burmeister
}

\author{
Simone L Garcia, Vera Lúcia CC Rodrigues*, Nancy L Garcia**, \\ Antenor N Ferraz Filho*, Maria Luiza S Mello/ ${ }^{+}$
}

\begin{abstract}
Departamento de Biologia Celular e Parasitologia, Instituto de Biologia **Departamento de Estatística, Instituto de Matemática, Estatística e Computação Científica, Unicamp, 13083-970 Campinas, SP, Brasil

*Sucen, 13840-000 Mogi-Guaçu, SP, Brasil
\end{abstract}

Survival and molting incidence were studied after heat $\left(40^{\circ} \mathrm{C}\right)$ and cold $\left(0^{\circ} \mathrm{C}\right)$ shocks in specimens of Panstrongylus megistus with the aim of establishing its response to temperature stress under laboratory rearing conditions and to understand occasional changes in the biological characteristics of specimens captured in nature. The response to the thermal shocks was found to vary as a function of the temperature and duration of the shock, developmental phase and sex of the specimens, and in certain cases, the insect habit and nourishment conditions. P. megistus specimens were found to be less resistant to the heat shock assay than Triatoma infestans, another reduviid species. The short cold shock affected survival of $\mathrm{P}$. megistus more than did the heat shock, survival of fully-nourished specimens being preferential. The response of adults to the short cold shock was affected by sex, males being generally less resistant. The insect sylvatic habit was found to seldom affect the thermal shock response established for specimens with domestic habit. A decrease in molting frequency and sometimes a slowdown of the molting rate were found after the short heat and cold shocks, possibly promoted by change in hormonal balance, and differing from patterns reported for $\mathrm{T}$. infestans. The results indicate that no generalization should be made for different reduviid species in terms of the effects of temperature shocks.

Key words: Panstrongylus megistus - heat shock - cold shock - survival - molting

Nymphs and adults of Triatoma infestans Klug have been reported to exhibit changes in survival and molting incidence when subjected to cold and heat shocks. The response to the thermal shocks was found to vary as a function of temperature, treatment duration, developmental stage, and sex (Rodrigues et al. 1991). In addition, under such experimental conditions, the Malpighian tubule epithelial cells of $T$. infestans specimens have exhibited changes in nuclear phenotypes involving nuclear fusion, heterochromatin unravelling, necrosis and apoptosis (Dantas \& Mello 1992, Tavares et al. 1997). Other stress factors such as starvation, gamma ionizing radiation, and heavy metals also induce similar nuclear changes (Mello 1983, Álvares-Garcia 1988, Mello et al. 1995).

\footnotetext{
This work was supported by the State of São Paulo Research Foundation (Fapesp, grant 95/1954-8) and the Brazilian Research and Development National Council (CNPq) and was part of a thesis presented by SLG to the Instituto de Biologia, Unicamp, in partial fulfillment of the requirements for the Masters degree.

${ }^{+}$Corresponding author. Fax: +55-19-289.3124. E-mail: mlsmello@obelix.unicamp.br

Received 11 May 1998

Accepted 26 August 1998
}

All of these data have been considered to be of importance for the establishment of optimal biological conditions for rearing $T$. infestans in the laboratory, where they are used for research and xenodiagnosis purposes, as well as in comparison with specimens obtained directly from the natural environment (Rodrigues et al. 1991, Dantas \& Mello 1992).

Panstrongylus megistus Burmeister is relevant because of its wide distribution, high rates of infection with Trypanosoma cruzi and geographically differing capacity to invade artificial ecotopes (Forattini et al. 1978, Forattini 1980). Since $P$. megistus differs from $T$. infestans in several biological characteristics, also when reared in the laboratory (Sherlock 1979), the determination of its response patterns to stress factors are deemed necessary for comparative purposes. In addition, $P$. megistus is known to exhibit behavioral diversification, since sylvatic populations of this species occur only in areas covered with perennial rain forest whereas domestic populations have developed in areas in which sometimes human behaviour changed natural forest to open land (Forattini 1980).

In the present study survival and molting patterns were determined for domestic and wild-descendant specimens of P. megistus after heat and 
cold shocks and compared to previously reported data for T. infestans.

\section{MATERIALS AND METHODS}

Third, fourth, and fifth instar nymphs and male and female adults of P. megistus Burmeister (Hemiptera, Reduviidae) domestic populations and fifth generation descendants from a sylvatic population reared in the laboratory of Sucen (Mogi Guaçu, SP) were used. Controls were maintained at $28^{\circ} \mathrm{C}$ and $80 \%$ relative humidity, conditions which have traditionally been used for rearing this insect in the laboratory of Sucen since 1980.

Experimental specimens were subjected to thermal shocks at $40^{\circ} \mathrm{C}$ and $0^{\circ} \mathrm{C}$ for $1 \mathrm{hr}$ and $12 \mathrm{hr}$. These temperatures were chosen because of operational facilities, the need to use relatively extreme temperatures in comparison to the control, and comparison with data previously described for T. infestans (Rodrigues et al. 1991).

Results for fully nourished specimens fed hen's blood $48 \mathrm{hr}$ prior to the shocks and for specimens subjected to a 15-day fasting period before the shocks were compared.
One hundred nymphs and 25 adult males and 25 adult females were used for each experiment.

Immediately after the thermal shocks the insects were returned to control conditions and monitored daily for about one month to investigate changes in survival rates and molting incidence. During this period the insects were fed once a week.

The survival curves and molting rates were compared statistically by the non-parametric MantelHantzel's procedure (Kalbfleish \& Prentice 1980).

\section{RESULTS}

The response of $P$. megistus specimens to thermal shock was found to vary as a function of temperature and duration of the shock, developmental phase and sex of the specimens (Tables I-III). It was also found to vary, under certain circumstances, with habit and nourishment conditions (Tables I-III). Patterns of response to heat and cold shocks in domestic specimens are illustrated in Figs 1 and 2.

The short heat shock had small effects on insect survival especially when considering nymphs, while the long heat shock was lethal to most specimens (Tables I-III).

TABLE I

Survival rate (\%) of Panstrongylus megistus nymphs (domestic habit) 33 days after thermal shocks (n, 100)

\begin{tabular}{|c|c|c|c|c|c|c|}
\hline \multirow{3}{*}{$\begin{array}{l}\text { Experimental } \\
\text { conditions }\end{array}$} & \multicolumn{6}{|c|}{ Nymphal instar } \\
\hline & \multicolumn{2}{|c|}{ Third } & \multicolumn{2}{|c|}{ Fourth } & \multicolumn{2}{|c|}{ Fifth } \\
\hline & A & $\mathrm{B}$ & A & B & $\mathrm{A}$ & B \\
\hline Control, $28^{\circ} \mathrm{C}$ & 96 & 95 & 96 & 84 & 95 & 86 \\
\hline \multicolumn{7}{|l|}{ Heat shock } \\
\hline $40^{\circ} \mathrm{C}, 1 \mathrm{hr}$ & 91 & 98 & 91 & 92 & 93 & 89 \\
\hline $40^{\circ} \mathrm{C}, 12 \mathrm{hr}$ & 0 & 0 & 0 & 0 & 0 & 18 \\
\hline \multicolumn{7}{|l|}{ Cold shock } \\
\hline $0^{\circ} \mathrm{C}, 1 \mathrm{hr}$ & 83 & 48 & 87 & 76 & 92 & 86 \\
\hline $0^{\circ} \mathrm{C}, 12 \mathrm{hr}$ & 24 & 0 & 23 & 17 & 3 & 0 \\
\hline
\end{tabular}

A: fully nourished specimens; B: moderately fasted specimens.

TABLE II

Survival rate (\%) of Panstrongylus megistus nymphs (sylvatic habit) 33 days after thermal shocks (n, 100)

\begin{tabular}{|c|c|c|c|c|c|c|}
\hline \multirow{3}{*}{$\begin{array}{l}\text { Experimental } \\
\text { conditions }\end{array}$} & \multicolumn{6}{|c|}{ Nymphal instar } \\
\hline & \multicolumn{2}{|c|}{ Third } & \multicolumn{2}{|c|}{ Fourth } & \multicolumn{2}{|c|}{ Fifth } \\
\hline & A & $\mathrm{B}$ & A & $\mathrm{B}$ & A & B \\
\hline Control, $28^{\circ} \mathrm{C}$ & 97 & 98 & 80 & 88 & 94 & 81 \\
\hline $\begin{array}{l}\text { Heat shock } \\
\qquad 40^{\circ} \mathrm{C}, 1 \mathrm{hr}\end{array}$ & 98 & 88 & 99 & 80 & 94 & 85 \\
\hline $\begin{array}{l}\text { Cold shock } \\
0^{\circ} \mathrm{C}, 1 \mathrm{hr} \\
0^{\circ} \mathrm{C}, 12 \mathrm{hr}\end{array}$ & $\begin{array}{r}92 \\
2\end{array}$ & $\begin{array}{l}60 \\
10\end{array}$ & $\begin{array}{r}100 \\
23\end{array}$ & $\begin{array}{l}65 \\
17\end{array}$ & $\begin{array}{l}77 \\
20\end{array}$ & $\begin{array}{r}62 \\
4\end{array}$ \\
\hline
\end{tabular}

A: fully nourished specimens; B: moderately fasted specimens. No survival after the shock at $40^{\circ} \mathrm{C}$ for $12 \mathrm{hr}$. 
TABLE III

Survival rate (\%) of Panstrongylus megistus adults 31 days after thermal shocks (n, 25)

\begin{tabular}{|c|c|c|c|c|c|c|c|c|}
\hline \multirow{3}{*}{$\begin{array}{l}\text { Experimental } \\
\text { conditions }\end{array}$} & \multicolumn{4}{|c|}{ Domestic habit } & \multicolumn{4}{|c|}{ Sylvatic habit } \\
\hline & \multicolumn{2}{|c|}{$\mathrm{A}$} & \multicolumn{2}{|c|}{ B } & \multicolumn{2}{|c|}{$\mathrm{A}$} & \multicolumn{2}{|c|}{$\mathrm{B}$} \\
\hline & G & $\mathrm{E}$ & G & $E$ & G & $\mathrm{E}$ & G & $\mathrm{E}$ \\
\hline Control, $28^{\circ} \mathrm{C}$ & 96 & 88 & 80 & 80 & 92 & 88 & 64 & 92 \\
\hline $\begin{array}{l}\text { Heat shock } \\
\qquad 40^{\circ} \mathrm{C}, 1 \mathrm{hr}\end{array}$ & 72 & 88 & 56 & 88 & 64 & 88 & 76 & 64 \\
\hline $\begin{array}{r}\text { Cold shock } \\
0^{\circ} \mathrm{C}, 1 \mathrm{hr}\end{array}$ & 8 & 52 & 20 & 36 & 36 & 36 & 32 & 64 \\
\hline
\end{tabular}

A: fully nourished specimens; B: moderately fasted specimens. No survival after the shocks at $40^{\circ} \mathrm{C}$ and $0^{\circ} \mathrm{C}$ for $12 \mathrm{hr}$.

The short cold shock was usually more effective than the short heat shock in promoting the death of nymphs and adults (Tables I-III). When the cold shock was extended for as long as $12 \mathrm{hr}$ it was always as lethal as the heat shock to adults (Table III) and to nymphs during certain developmental stages and under different habit and nourishment conditions (Tables I, II). However, under other conditions it was less lethal than the long heat shock (Tables I, II).

Adult males were generally less resistant than adult females to short heat and cold shocks except for sylvatic specimens maintained under moderate fasting conditions (Table III).

Visually detected differences and similarities when comparing the survival curves were usually confirmed by the Mantel-Hantzel test (data not shown), with a few exceptions. One concerned the survival curve of moderately fasted third instar nymphs with a sylvatic habit which did not appear visually to be greatly affected by the short heat shock, but was demonstrated to differ statistically from the control curve $(\mathrm{W}, 55.7$; df, 1 ; p-value, $0.0053)$. The other exception concerned the curve for moderately fasted adult males with a domestic habit, which appeared visually to differ from the control curve but not significantly so (W, 4.6; df, 1; p-value, 0.0312).

Molting was drastically affected in terms of frequency and time by the cold shock, differing from the much gentler effect promoted by the heat shock (Figs 1-2). This fact was statistically confirmed, except for the cases pointed out in Table IV. No difference was detected as a function of the popu-

TABLE IV

Comparison of molting rates by the Mantel-Hantzel test

\begin{tabular}{|c|c|c|c|c|}
\hline Insects & Compared conditions & W & d.f. & p-value \\
\hline \multirow[t]{2}{*}{$\begin{array}{l}\text { Fully nourished third instar } \\
\text { nymphs-domestic habit }\end{array}$} & $\begin{array}{l}\text { Control vs } 40^{\circ} \mathrm{C} \\
v s 0^{\circ} \mathrm{C}(1 \mathrm{hr})\end{array}$ & 105.2 & 2 & 0.0000 \\
\hline & $\begin{array}{l}\text { Control vs } \\
40^{\circ} \mathrm{C}(1 \mathrm{hr})\end{array}$ & 6.4 & 1 & 0.0112 \\
\hline \multirow[t]{2}{*}{$\begin{array}{l}\text { Moderately fasted third instar } \\
\text { nymphs- sylvatic habit }\end{array}$} & $\begin{array}{l}\text { Control vs } 40^{\circ} \mathrm{C} \\
v s 0^{\circ} \mathrm{C}(1 \mathrm{hr})\end{array}$ & 81.5 & 2 & 0.0000 \\
\hline & $\begin{array}{l}\text { Control vs } \\
40^{\circ} \mathrm{C}(1 \mathrm{hr})\end{array}$ & 5.7 & 1 & 0.0172 \\
\hline $\begin{array}{l}\text { Moderately fasted fourth instar } \\
\text { nymphs-sylvatic habit }\end{array}$ & $\begin{array}{l}\text { Control vs } 40^{\circ} \mathrm{C} \\
\text { vs } 0^{\circ} \mathrm{C}(1 \mathrm{hr})\end{array}$ & 3.6 & 2 & 0.1645 \\
\hline $\begin{array}{l}\text { Fully nourished fifth instar } \\
\text { nymphs-domestic habit }\end{array}$ & $\begin{array}{l}\text { Control vs } 40^{\circ} \mathrm{C} \\
v s 0^{\circ} \mathrm{C}(1 \mathrm{hr})\end{array}$ & 0.0 & 2 & 0.9979 \\
\hline \multirow[t]{2}{*}{$\begin{array}{l}\text { Fully nourished fifth instar } \\
\text { nymphs-sylvatic habit }\end{array}$} & $\begin{array}{l}\text { Control vs } 40^{\circ} \mathrm{C} \\
v s 0^{\circ} \mathrm{C}(1 \mathrm{hr})\end{array}$ & 77.9 & 2 & 0.0000 \\
\hline & $\begin{array}{l}\text { Control vs } \\
40^{\circ} \mathrm{C}(1 \mathrm{hr})\end{array}$ & 14. 4 & 1 & 0.0001 \\
\hline
\end{tabular}


Heat and Cold Shock Effects in P. megistus - Simone L Garcia et al.

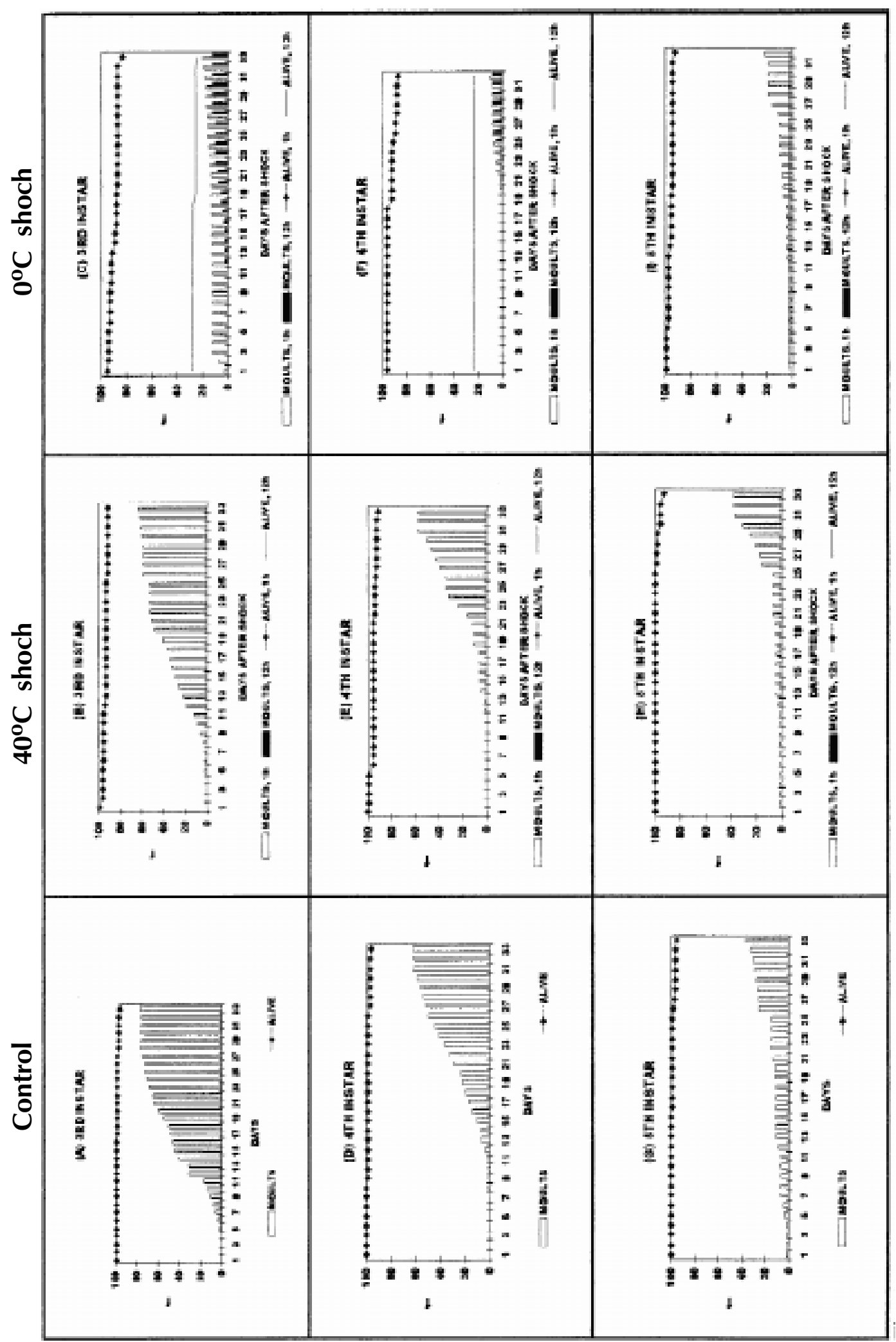

Fig.1: survival and molting incidence for fully nourished nymphs of Panstrongylus megistus with domestic habit; f: frequency $(\%)$. 


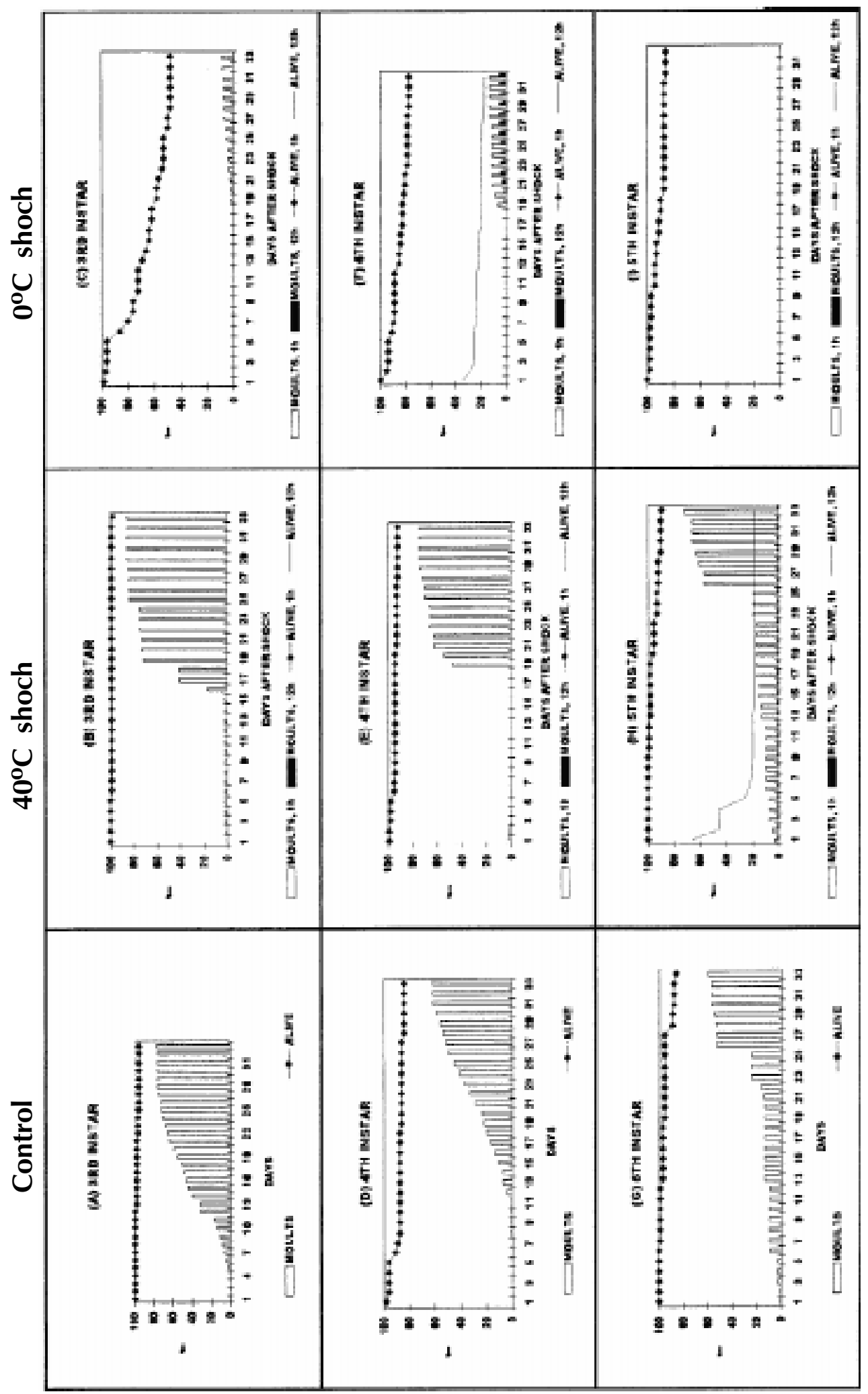

Fig. 2: survival and molting incidence for moderately fasted nymphs of Panstrongylus megistus with domestic habit; f: frequency (\%). 
lation habit, with exception of a decreased frequency of molts in fourth (under both nourishment conditions) and fifth instar (under moderate fasting) domiciliary nymphs subjected to the cold shock.

\section{DISCUSSION}

Although heat shock proteins (hsp) have not been reported for Triatominae, the participation of these proteins in survival of $P$. megistus specimens after the short heat shock is suggested. Thermotolerance typical of the hsp action (Lindquist 1986) has been revealed to develop in $P$. megistus specimens subjected to sequential shocks, inclusive promoting the survival of specimens shocked for a $12 \mathrm{hr}$ period (Garcia et al. 1998).

Since decreased survival rates were found in $P$. megistus adults, possibly there is a variable efficiency of the hsp along the insect lifetime. In addition, considering that mortality was attained after most insects in the various developmental stages were subjected to a $12 \mathrm{hr}$ exposure to $40^{\circ} \mathrm{C}$, hsp appears not to be qualitatively or quantitalively efficient enough to protect them for long periods of time directly exposed to this temperature. In comparison to T. infestans, P. megistus specimens were found to be less resistant to the heat shock assay, which may be due to differences in their hsp mechanistic action, including differences in their optimal temperature for the hsp induction response (Lindquist 1986).

Considering the response of $P$. megistus specimens to cold shock especially for $12 \mathrm{hr}$, it is assumed that cryoprotectants do not exist in these insects, which is probably also the case for $T$. infestans (Rodrigues et al. 1991).

P. megistus adults of both habits did not survive long shocks at all. This observation was in contrast to Wigglesworth's (1984) report which states that insect size favours survival of the largest specimens after stress.

The short cold shock, while affecting survival of nymphs and adults of $P$. megistus more than did the heat shock, allowed some specimens to survive at least for as long as one month after the shock. Based on data for other insect species, it is hypothesized that hsp synthesis may also be engaged in a certain protection of $P$. megistus organism against protein abnormalities resulting from the cold shock, mainly when it did not extend for very long periods of time and affected fully nourished specimens (Chen et al. 1987, Burton et al. 1988, Komatsu et al. 1996).

The preferential survival of fully nourished nymphs of $P$. megistus, when subjected to thermal shocks, contrasts with the response of $T$. infestans to stress factors such as heavy metals, with starved specimens exhibing a higher survival frequency associated with the increased formation of layered concretions in the insect excretory organs (Mello et al. 1995).

The response of $P$. megistus adults to the short cold shock did not follow any apparent rule, except by sex. The generally differential resistance to thermal shocks in adults as a function of sex is mostly in agreement with studies by others which demonstrated that either under favorable or adverse laboratory conditions (starvation and gamma radiation), P. megistus males are usually less resistant than females (Lima et al. 1987, Vercosa et al. 1993). The only exception concerns longer survival of males after the short heat shock, when considering moderately fasted specimens of sylvatic habit. In fact, this was one of the few responses to thermal shocks in P. megistus which were found to vary advantageously as a function of the insect sylvatic habit.

The decrease in molting frequency and in some cases the slowdown in the molting rate with advancing time after the short heat and cold shocks was probably due to a change in hormonal balance promoted by the thermal shock, possibly sustaining the juvenile hormone production as suggested for Rhodnius prolixus (Wigglesworth 1984).

The short heat shock in P. megistus was more involved with the slowdown of the molting rate, a slight effect compared to those observed in $T$. infestans under the same experimental conditions (Rodrigues et al. 1991). On the other hand, the short cold shock induced a similar response in fourth and fifth instar nymphs of both species, i.e., not only a slower rate but also a fall in the molting frequency. While this was also evident for third instar nymphs of $P$. megistus, the short cold shock, like the short heat shock, accelerated the molting rate of $T$. infestans.

The shock for $1 \mathrm{hr}$ at $40^{\circ} \mathrm{C}$ was thus apparently not severe to $P$. megistus nymphs up to the point of affecting drastically their survival and molting, while it differently affected $T$. infestans nymphs as a function of their developmental phase (Rodrigues et al. 1991).

The different patterns of response to thermal shocks when comparing $P$. megistus and $T$. infestans emphasize that no generalization is advisable when one intends to attain optimal conditions for rearing reduviid colonies in the laboratory or to understand altered biological characteristics of their specimens captured in natural ecotopes. In favor of this hypothesis is the report of Buxton (1931) that $R$. prolixus specimens attain their thermal death-point after being exposed for 1 hr at $43^{\circ} \mathrm{C}$. 


\section{ACKNOWLEDGMENTS} Silva.

To the technical support of Mr Pedro Ribeiro da

\section{REFERENCES}

Álvares-Garcia RS 1988. Efeitos da Radiação Gama sobre os Fenótipos Nucleares de Alguns Tipos Celulares de Triatoma infestans Klug (Hemiptera, Reduviidae), MSc Thesis, Unicamp, Campinas, 104 pp.

Burton V, Mitchell HK, Young P, Petersen NS 1988. Heat shock protein against cold stress of Drosophila melanogaster. Mol Cell Biol 8: 3550-3552.

Buxton PA 1931. The thermal death-point of Rhodnius (Rhynchota, Heteroptera) under controlled conditions of humidity. J Exp Biol 8: 275-278.

Chen CP, Denlinger DL, Lee RE 1987. Cold shock injury and rapid cold hardening in the flesh fly Sarcophaga crassipalpis. Physiol Zool 60: 297-304.

Dantas MM, Mello MLS 1992 Changes in the nuclear phenotypes of Triatoma infestans Klug, induced by thermal shocks. Rev Bras Genet 15: 509-519.

Forattini OP 1980. Biogeografia, origem e distribuição da domiciliação de triatomíneos no Brasil. Rev Saú Públ 14: 265-299.

Forattini OP, Ferreira OA, Rocha-E-Silva EO, Rabello EX 1978. Aspectos ecológicos da tripanossomíase americana. XII. Variação regional da tendência de Panstrongylus megistus à domiciliação. Rev Saú Públ 12: 209-233.

Garcia SL, Rodrigues VLCC, Mello MLS 1998. Estudo da termotolerância em Panstrongylus megistus Burmeister após choque hipertérmico. Genet Mol Biol (Suppl) (in press).

Kalbfleish JD, Prentice RL 1980. The Statistical Analysis of Failure Time Data, John Wiley \& Sons, New York, $321 \mathrm{pp}$.

Komatsu Y, Kodama O, Fujita K 1996. Heat shock treat- ment reduces in situ temperature in yeast at sub-lethal high temperature. Cell Mol Biol 42: 839-845.

Lima MM, Jurberg P, Almeida JR 1987. Behavior of triatomines (Hemiptera: Reduviidae) vectors of Chagas' disease. IV. Fecundity, fertility and longevity of Panstrongylus megistus (Burm., 1835) pairs and virgin females starved under laboratory conditions. Mem Inst Oswaldo Cruz 82: 501-509.

Lindquist S 1986. The heat shock response. Ann Rev Biochem 55: 1151-1191.

Mello MLS 1983. Cytochemical properties of euchromatin and heterochromatin. Histochem J 15: 739751.

Mello MLS, Kubrusly FS, Randi MA, Rodrigues VLCC, Ferraz Filho AN 1995. Effects of heavy metals on chromatin supraorganization nuclear phenotypes, and survival of Triatoma infestans. Entomol Exp Appl 74: 209-218.

Rodrigues VLCC, Mello MLS, Ferraz Filho AN, Dantas MM 1991. Sobrevivência e ocorrência de muda em Triatoma infestans Klug (Hemiptera, Reduviidae) após choque de temperatura. Rev Saú Públ 25: 461467.

Sherlock IA 1979. Vetores, p. 42-88. In Z Brener, Z Andrade (eds), Trypanosoma cruzi e Doença de Chagas, Guanabara Koogan, Rio de Janeiro.

Tavares MCH, Dantas MM, Rodrigues VLCC, Mello MLS 1997. Alterações em fenótipos nucleares, com ênfase na apoptose, em túbulos de Malpighi de Triatoma infestans Klug após choque hipertérmico, p. $65,43^{\circ}$ Congresso Nacional de Genética, Goiânia, Brasil.

Vercosa P, Falcão PHDB, Furtado AF 1993. Effects of gamma irradiation on the reproductive capacity and the longevity of Panstrongylus megistus (Hemiptera: Reduviidae). Mem Inst Oswaldo Cruz 88: 195-201. Wigglesworth VB 1984. Insect Physiology, 8th ed., Chapman and Hall, London, 191 pp. 
Heat and Cold Shock Effects in P. megistus - Simone L Garcia et al. 